\title{
NOTES
}

\section{WHITMAN ON ROBERT BURNS: A FOOTNOTE}

I would like to add a footnote to Gary Scharnhorst's essay, "Whitman on Robert Burns: An Early Essay Recovered" (Walt Whitman Quarterly Review 13. [Spring 1996], 217-220). I have in my possession a slip of paper which Alfred Goldsmith, the well-known Whitman bibliophile and bookseller, sold to me in 1947, nearly half a century ago. It is one of those scraps of paper on which Whitman jotted down in pencil a sentence or an idea which had just occurred to him. He collected these scraps and pinned them together so as not to lose them. He could thus use them later after putting them in order like the pieces of a mosaic or a puzzle. The pin-pricks are still visible on the specimen I have.

After he copied this fragment into a draft of an essay, Whitman put a pen stroke through it and, to remember its destination, wrote in ink "in the Burns" and circled it. The text probably corresponds to the rough draft of the earliest version of his essay on Burns. It is reproduced on the back cover of this issue of WWQR and also in my book The Evolution of Walt Whitman (Harvard University Press, 1962), 2:223. The fragment reads:

The Iliad \& the Odyssey express war courage craft in situations of danger, the sense of leadership, heroic but animal appetites, etc

the Shakespearean the ideal of the Feudal lord, the master, warlike ambitious, arrogant

In Whitman's published essay on Burns, these notes are expanded into the following sentences:

The classical Iliad and the Odyssey express war, courage, craft, full-grown heroism, \&c., for the whole human race, in situations of danger, the sense of command and leadership, emulation and god-like even though animal appetites. The English Shakesperian compositions on vertebres and framework of the primary passions portray the spirit and letter of the feudal world, the Norman lord, ambitious and arrogant, taller and nobler than common men, with much underplay and gusts of heat and cold, volcanoes and stormy seas. 